\title{
The Influence of Dopant Concentration on Optical-Electrical Features of Quantum Dot-Sensitized Solar Cell
}

\author{
Dang Huu Phuc ${ }^{1,2}$, Ha Thanh Tung ${ }^{3, *(\mathbb{D}}$, Van-Cuong Nguyen ${ }^{4}$ and My Hanh Nguyen Thi ${ }^{5}$ \\ 1 Laboratory of Applied Physics, Advanced Institute of Materials Science, Ton Duc Thang University, \\ Ho Chi Minh City 70880, Vietnam; danghuuphuc@tdtu.edu.vn \\ 2 Faculty of Applied Sciences, Ton Duc Thang University, Ho Chi Minh City 70880, Vietnam \\ 3 Faculty of Physics, Dong Thap University, Cao Lãnh 870000, Dong Thap Province, Vietnam \\ 4 Faculty of Chemical Engineering, Industrial University of Ho Chi Minh City, 12 Nguyen Van Bao, Go Vap, \\ Ho Chi Minh City 70000, Vietnam \\ 5 Faculty of Mechanical Engineering, Industrial University of Ho Chi Minh City, 12 Nguyen Van Bao Street, \\ Ward 4, Go Vap, Ho Chi Minh City 70000, Vietnam \\ * Correspondence: httung@dthu.edu.vn
}

Citation: Huu Phuc, D.; Thanh Tung, H.; Nguyen, V.-C.; Hanh Nguyen Thi, $M$. The Influence of Dopant Concentration on Optical-Electrical Features of Quantum Dot-Sensitized Solar Cell. Molecules 2021, 26, 2865. https://doi.org/10.3390/ molecules26102865

Academic Editor: Xin Min

Received: 11 April 2021

Accepted: 10 May 2021

Published: 12 May 2021

Publisher's Note: MDPI stays neutral with regard to jurisdictional claims in published maps and institutional affiliations.

Copyright: (c) 2021 by the authors. Licensee MDPI, Basel, Switzerland. This article is an open access article distributed under the terms and conditions of the Creative Commons Attribution (CC BY) license (https:/ / creativecommons.org/licenses/by/ $4.0 /)$.

\begin{abstract}
In this study, $\mathrm{TiO}_{2} / \mathrm{CdS} / \mathrm{Cd}_{\mathrm{x}} \mathrm{Cu}_{1-\mathrm{x}} \mathrm{Se}, \mathrm{TiO}_{2} / \mathrm{CdS} / \mathrm{Cd}_{\mathrm{x}} \mathrm{Mn}_{1-\mathrm{x}} \mathrm{Se}$, and $\mathrm{TiO}_{2} / \mathrm{CdS} / \mathrm{Cd}_{\mathrm{x}} \mathrm{Ag}_{2-2 \mathrm{x}} \mathrm{Se}$ thin films were synthesized by chemical bath deposition for the fabrication of photoanode in quantumdot-sensitized solar cells. As a result, the structural properties of the thin films have been studied by X-ray diffraction, which confirmed the zinc Blende structure in the samples. The optical films were researched by their experimental absorption spectra with different doping concentrations. Those results were combined with the Tauc correlation to estimate the absorption density, the band gap energy, valence band and conduction band positions, steepness parameter, and electron-phonon interaction. Furthermore, the electrical features, electrochemical impedance spectrum and photocurrent density curves were carried out. The result was used to explain the enhancing performance efficiency.
\end{abstract}

Keywords: dopant concentration; quantum dots; cadmium selenite; cadmium sulfur

\section{Introduction}

In recent years, nanocrystals have attracted attention from scientists globally due to their advanced features, such as high absorptivity, durable material composition, and efficient ruling of energies [1] Because of these properties, these semiconductors can be used in various fields, for example, as photoelectronics, photodetectors, quantum-dot-sensitized solar cell (QDSSCs), and other types of photoelectronic [2].

In recent decades, quantum dots (QDs) have attracted attention from scientists globally because of their unique properties, such as: high adsorption coefficient, stable chemical composition, and efficient control of the band gap $\left(E_{g}\right)[3,4]$. Because of these properties, these semiconductors can be used in various fields, such as: photoelectronics, photodetectors, quantum-dot-sensitized solar cells, and other types of solar cells [5-7]. Over the years, CdSe QDs have been extensively investigated by scientists worldwide. They were applied to the photoanodes in the QDSSCs owing to their low cost, easy fabrication, and high stable chemical composition. However, the resistance of the CdSe films is significantly larger, and the energies of these films are smaller than those of bulk CdSe. Therefore, the amount of excited electrons generated in the conduction band (CB) of CdSe QDs to be transferred to the $\mathrm{CB}$ of $\mathrm{TiO}_{2}$ semiconductor was considerably low. Recently, a new technique has been applied to improve the current density and energy conversion of QDSSCs using CdSe QDs doped with transition metals such as $\mathrm{Mg}$ [5], and Co [8]. The exchange interaction between the transition metal and the electronic states of the CdSe QDs is fundamental for the study of optical and electrical properties of the QDSSCs. Generally, because of the doping of the transition metals in nano semiconductors, $E_{g}$ and high-absorbing photons are generated in different regions. As a result, the photocurrent density, which is due to the 
movement of the excited electrons in the circuit, increases [9,10]. Moreover, after doping, the recombination and dynamic resistance of $\mathrm{TiO}_{2} / \mathrm{QDs}$ and diffusion resistance of $\mathrm{TiO}_{2}$ film $\left(\mathrm{R}_{\mathrm{ct} 2}\right)$, and counter electrode/electrolyte $\left(\mathrm{R}_{\mathrm{ct} 1}\right)$ decrease significantly [11].

In previous articles, $\mathrm{TiO}_{2} / \mathrm{CdS} / \mathrm{Cd}_{\mathrm{x}} \mathrm{Cu}_{1-\mathrm{x}} \mathrm{Se}\left(\right.$ as $0 \% \leq x \leq 5 \%$, at $\%$ ), $\mathrm{TiO}_{2} / \mathrm{CdS} / \mathrm{Cd}_{\mathrm{x}}$ $\mathrm{Mn}_{1-\mathrm{x}} \mathrm{Se}\left(\right.$ as $0 \% \leq x \leq 40 \%$, at $\%$ ), and $\mathrm{TiO}_{2} / \mathrm{CdS} / \mathrm{Cd}_{x} \mathrm{Ag}_{2-2 \mathrm{x}} \mathrm{Se} 0 \% \leq x \leq 40 \%$, at $\%$ thin films have investigated and optimized characterizations of the materials as morphological analysis through FE-SEM, TEM; structure through XRD, Raman, EDX; optical properties as UV-Viss; lifetimes of excited electrons for fabricating photoanode in QDSSCs. In this research, we focus on the optical-electrical properties by their experimental absorption spectra with different doping concentrations and combination with the Tauc correlation to estimate the absorption density, the band gap energy, valence band and conduction band positions, steepness parameter, and electron-phonon interaction in the samples.

\section{Results and Discussion}

\subsection{Structural Characterization}

The structural $\mathrm{TiO}_{2} / \mathrm{CdS} / \mathrm{Cd}_{\mathrm{x}} \mathrm{Cu}_{1-\mathrm{x}} \mathrm{Se}, \mathrm{TiO}_{2} / \mathrm{CdS} / \mathrm{Cd}_{\mathrm{x}} \mathrm{Mn}_{1-\mathrm{x}} \mathrm{Se}$, and $\mathrm{TiO}_{2} / \mathrm{CdS} / \mathrm{Cd}_{\mathrm{x}}$ $\mathrm{Ag}_{2-2 \mathrm{x}} \mathrm{Se}$ QDSSCs have been performed by X-ray diffraction. The obtained X-ray diffraction patterns are shown in Figure 1. For all thin films, the chart lists various parameters calculated from the diffraction peaks at $43.2^{\circ}$ and $50.1^{\circ}$ corresponding to the (220) and (311) crystal planes, respectively, of CdS, and CdSe zinc blende structure (JCPDS No. 88-2346 and JCPDS No. 41-1019) [12]. The peaks at $25.4^{\circ}, 37.6^{\circ}, 47.5^{\circ}$ and $54.5^{\circ}$ correspond to the (101), (004), (200), and (211) planes of the $\mathrm{TiO}_{2}$ Anatase structure [13]. In addition, the peak at $25^{\circ} \mathrm{C}$ for $\mathrm{TiO}_{2} / \mathrm{CdS} / \mathrm{Cd}_{\mathrm{x}} \mathrm{Cu}_{1-\mathrm{x}} \mathrm{Se}, \mathrm{TiO}_{2} / \mathrm{CdS} / \mathrm{Cd}_{x} \mathrm{Mn}_{1-\mathrm{x}} \mathrm{Se}$, and $\mathrm{TiO}_{2} / \mathrm{CdS} / \mathrm{Cd}_{\mathrm{x}} \mathrm{Ag}_{2-2 \mathrm{x}} \mathrm{Se}$ films conducted from the FTO, because all films were coated on the FTO [13].

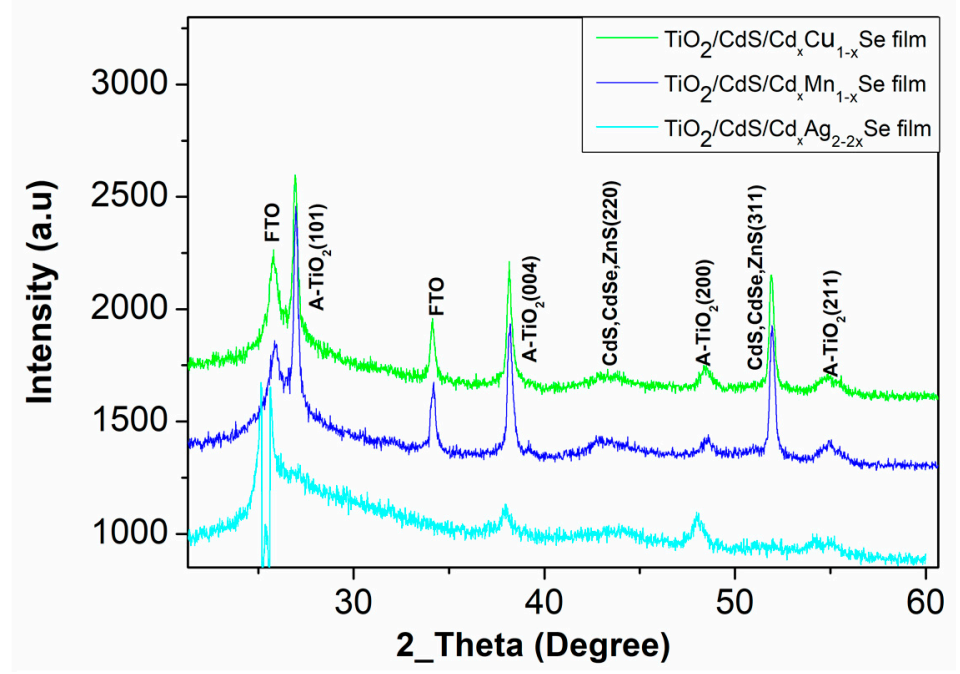

Figure 1. The X-ray diffraction of the $\mathrm{TiO}_{2} / \mathrm{CdS} / \mathrm{Cd}_{\mathrm{x}} \mathrm{Cu}_{1-\mathrm{x}} \mathrm{Se}$, and $\mathrm{TiO}_{2} / \mathrm{CdS} / \mathrm{Cd}_{\mathrm{x}} \mathrm{Mn}_{1-\mathrm{x}} \mathrm{Se}$ and $\mathrm{TiO}_{2} / \mathrm{CdS} / \mathrm{Cd}_{x} \mathrm{Ag}_{2-2 \mathrm{x}} \mathrm{Se}$ QDSSCs.

\subsection{Optical Characterization}

In photovoltaic cells, both the optical and electrical features of component materials must be investigated extensively. In this study, the absorption spectra, transmission, and reflection spectra of QDSSCs were recorded using UV-Vis. From the absorption spectra, we can determine various optical parameters, such as the absorption coefficient, $E_{g}$ of materials to control further band tail and study the defect states inside materials. $\mathrm{TiO}_{2} / \mathrm{CdS} / \mathrm{Cd}_{\mathrm{x}} \mathrm{Cu}_{1-\mathrm{x}} \mathrm{Se}, \mathrm{TiO}_{2} / \mathrm{CdS} / \mathrm{Cd}_{\mathrm{x}} \mathrm{Mn}_{1-\mathrm{x}} \mathrm{Se}$, and $\mathrm{TiO}_{2} / \mathrm{CdS} / \mathrm{Cd}_{\mathrm{x}} \mathrm{Ag}_{2-2 \mathrm{x}} \mathrm{Se}$ films recorded approximately $11.7 \mu \mathrm{m}, 12.675 \mu \mathrm{m}$, and $13.013 \mu \mathrm{m}$ of thickness from Figure 2, respectively. 


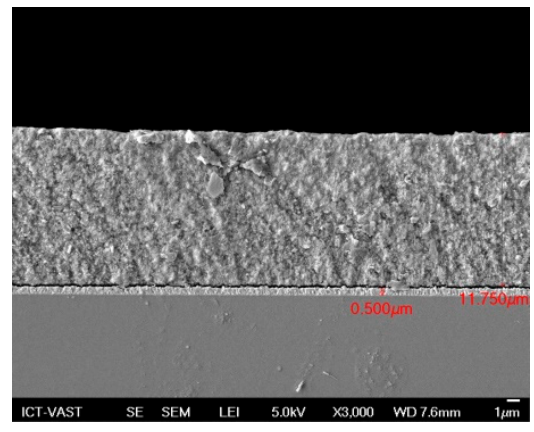

(a)

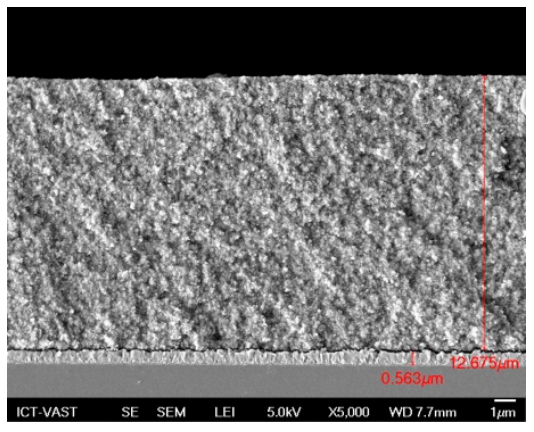

(b)

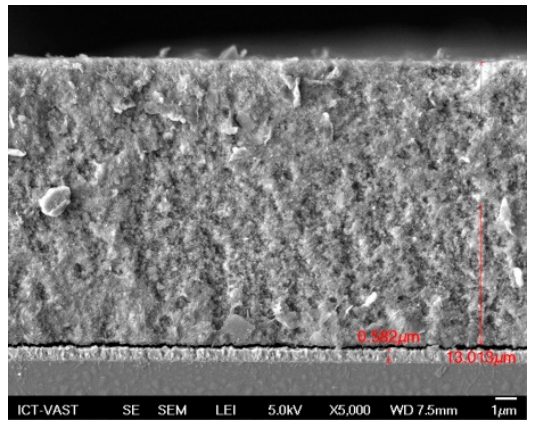

(c)

Figure 2. The FE-SEM of (a) $\mathrm{TiO}_{2} / \mathrm{CdS} / \mathrm{Cd}_{\mathrm{x}} \mathrm{Cu}_{1-\mathrm{x}} \mathrm{Se}$, (b) $\mathrm{TiO}_{2} / \mathrm{CdS} / \mathrm{Cd}_{\mathrm{x}} \mathrm{Mn}_{1-\mathrm{x}} \mathrm{Se}$, and (c) $\mathrm{TiO}_{2} / \mathrm{CdS} / \mathrm{Cd}_{\mathrm{x}} \mathrm{Ag}_{2-2 x} \mathrm{Se}$ films .

In Figure $3 \mathrm{a}$, the absorbance density of the $\mathrm{TiO}_{2} / \mathrm{CdS} / \mathrm{Cd}_{\mathrm{x}} \mathrm{Cu}_{1-\mathrm{x}} \mathrm{Se}, \mathrm{TiO}_{2} / \mathrm{CdS} / \mathrm{Cd}_{\mathrm{x}}$ $\mathrm{Mn}_{1-x} \mathrm{Se}$, and $\mathrm{TiO}_{2} / \mathrm{CdS} / \mathrm{Cd}_{x} \mathrm{Ag}_{2-2 \mathrm{x}} \mathrm{Se}$ thin films significantly increased by approximately $17 \%$, when compared with undoped film with that of $\mathrm{TiO}_{2} / \mathrm{CdS} / \mathrm{Cd}_{x} \mathrm{Cu}_{1-x}$ Se photoanode. Moreover, the absorption density of the $\mathrm{TiO}_{2} / \mathrm{CdS} / \mathrm{Cd}_{x} \mathrm{Ag}_{2-2 \mathrm{x}} \mathrm{Se}$ thin films decreased by approximately $11 \%$, when compared with $\mathrm{TiO}_{2} / \mathrm{CdS} / \mathrm{Cd}_{\mathrm{x}} \mathrm{Cu}_{1-x} \mathrm{Se}$ thin films. Furthermore, the absorption density of $\mathrm{TiO}_{2} / \mathrm{CdS} / \mathrm{Cd}_{\mathrm{x}} \mathrm{Cu}_{1-\mathrm{x}} \mathrm{Se}, \mathrm{TiO}_{2} / \mathrm{CdS} / \mathrm{Cd}_{\mathrm{x}} \mathrm{Mn}_{1-\mathrm{x}} \mathrm{Se}$, and $\mathrm{TiO}_{2} / \mathrm{CdS} / \mathrm{Cd}_{\mathrm{x}} \mathrm{Ag}_{2-2 \mathrm{x}} \mathrm{Se}$ photoanodes shifted towards a longer wavelength (from $507 \mathrm{~nm}$ for undoped films to $605 \mathrm{~nm}$ for doped films). This is attributed to the replacement of the $\mathrm{Cd}$ atoms by the metal atoms in the films and a proper crystallization of the films corresponding to a suitable doping-concentration-reducing effect state [14]. The $605 \mathrm{~nm}$ absorption peak of the $\mathrm{TiO}_{2} / \mathrm{CdS} / \mathrm{Cd}_{\mathrm{x}} \mathrm{Cu}_{1-x} \mathrm{Se}$ film was attributed to the transition of the $V B$ of Se to d-state of $\mathrm{Cu}$ dopant in the $E_{g}$ of pure CdSe QDs [15].

From the UV-Vis spectra, using the Tauc relation in Equation (1), we variously determined the $E_{g}$ of the $\mathrm{TiO}_{2} / \mathrm{CdS} / \mathrm{Cd}_{\mathrm{x}} \mathrm{Cu}_{1-\mathrm{x}} \mathrm{Se}, \mathrm{TiO}_{2} / \mathrm{CdS} / \mathrm{Cd}_{\mathrm{x}} \mathrm{Mn}_{1-\mathrm{x}} \mathrm{Se}$, and $\mathrm{TiO}_{2} / \mathrm{CdS} / \mathrm{Cd}_{\mathrm{x}}$ $\mathrm{Ag}_{2-2 x}$ Se films with dopants [16]

$$
\alpha h v=\alpha_{o}\left(h v-E_{g}\right)^{n}
$$

where $\alpha$ is noted as a coefficient of light coming adsorption, $h v$ is noted as a light coming energy, $\alpha_{0}$ is not the change factor, CdSe QDs has the direct band gap, and $n=0.5$. After plotting Equation (1) in Figure $3 b, E_{g}$ of the films was estimated and recorded (shown in Table 1).

Figure $3 \mathrm{~b}, \mathrm{c}$ illustrates the valuable $E_{g}$ for CdSe-doped photoanodes varying from $1.87 \mathrm{eV}$ to $1.78 \mathrm{eV}$, which is smaller than that without doped photoanode $(2.08 \mathrm{eV})$. Furthermore, by observation, the $E_{g}$ values of CdSe-doped photoanodes depended significantly on the change in dopants. Here, the reduced $E_{g}$ of the doped films resulted from two factors: an increase in particle size after doping [17], and a change in force density on account of the presence of $\mathrm{Cu}-\mathrm{Se}, \mathrm{Mn}-\mathrm{Se}$, and $\mathrm{Ag}$-Se pairs in the extended lattice at the expense of Cd-Se in the host lattice [18]. Therefore, the dopant energy levels, called transition energies, are presented in the $E_{g}$ of pure CdSe QDs. Subsequently, these photons obtain energy below $E_{g}$ of pure CdSe nano semiconductor, which can be absorbed at dopant energy levels before they are transferred to the $C B$ of pure CdSe semiconductor. Therefore, JSC was significantly increased on account of a large number of absorbed photons and, consequently, the absorption peak shifted towards to a longer wavelength. Furthermore, both the conduction band and valence band positions of the $\mathrm{TiO}_{2} / \mathrm{CdS} / \mathrm{Cd}_{x} \mathrm{Cu}_{1-x} \mathrm{Se}$, $\mathrm{TiO}_{2} / \mathrm{CdS} / \mathrm{Cd}_{\mathrm{x}} \mathrm{Mn}_{1-\mathrm{x}} \mathrm{Se}$, and $\mathrm{TiO}_{2} / \mathrm{CdS} / \mathrm{Cd}_{\mathrm{x}} \mathrm{Ag}_{2-2 \mathrm{x}} \mathrm{Se}$ films were estimated by the Tauc formula and listed in Table 1. Obtained $C B$ values of $-3.98,-3.7$, and $-4.1 \mathrm{eV}$ corresponding to the $\mathrm{TiO}_{2} / \mathrm{CdS} / \mathrm{Cd}_{\mathrm{x}} \mathrm{Cu}_{1-\mathrm{x}} \mathrm{Se}, \mathrm{TiO}_{2} / \mathrm{CdS} / \mathrm{Cd}_{\mathrm{x}} \mathrm{Mn}_{1-\mathrm{x}} \mathrm{Se}$, and $\mathrm{TiO}_{2} / \mathrm{CdS} / \mathrm{Cd}_{\mathrm{x}} \mathrm{Ag}_{2-2 \mathrm{x}} \mathrm{Se}$ films, respectively, are higher than the $C B$ value of $-4.105 \mathrm{eV}$ of pure CdSe QDs. Therefore, the presence of doping metals, which has increased the $C B$ value in the doped films com- 
pared to that in the undoped CdSe QDs, aids in the transition of excited electrons from the CdSe QDs to $\mathrm{TiO}_{2}$.

Table 1. $E_{g}, C B$, and $V B$ were estimated by Tauc equation and the band tail, $\sigma, E_{e-p}$ were obtained from the absorption spectra.

\begin{tabular}{cccccccc}
\hline Atom $\%$ & $E_{g}(\mathbf{e V})$ & $\boldsymbol{X}(\mathbf{e V})$ & $E_{C B}(\mathbf{e V})$ & $E_{V B}(\mathbf{e V})$ & $E_{U}(\mathrm{eV})$ & $\sigma(\mathrm{eV})$ & $E_{e-p}(\mathrm{eV})$ \\
\hline $\mathrm{CdSe}$ film & 2.08 & 5.145 & -4.105 & -6.2 & 0.786 & 0.033 & 20.25 \\
$\mathrm{Cd}_{\mathrm{x}} \mathrm{Cu}_{1-\mathrm{x}}$ Se film & 1.87 & 4.91 & -3.98 & -5.85 & 2.11 & 0.012 \\
$\mathrm{Cd}_{\mathrm{x}} \mathrm{Mn}_{1-\mathrm{x}}$ Se film & 1.79 & 4.62 & -3.7 & -5.5 & 2.33 & 0.011 & 54.5 \\
$\mathrm{Cd}_{\mathrm{x}} \mathrm{Ag}_{2-2 \mathrm{x}}$ Se film & 1.78 & 4.99 & -4.1 & -5.88 & 1.26 & 0.0205 & 32.6 \\
\hline
\end{tabular}

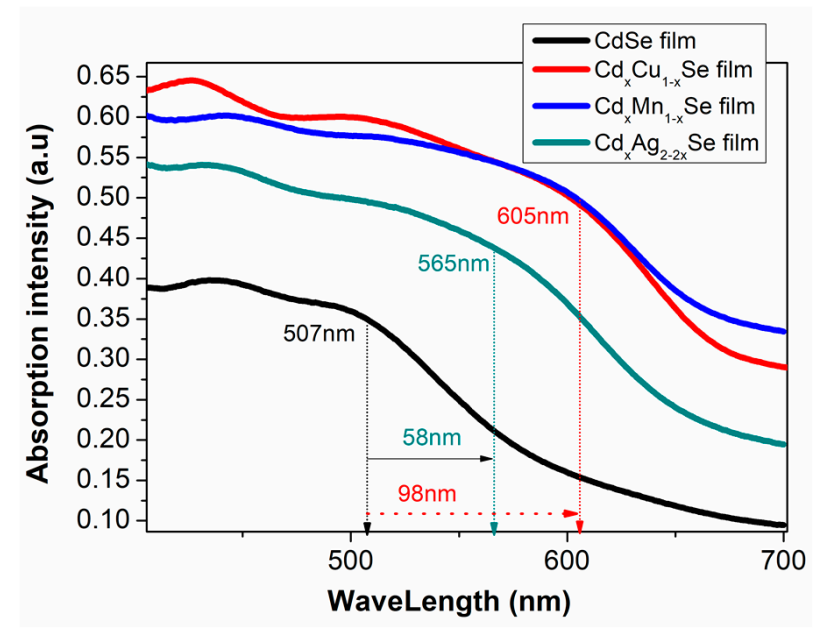

(a)

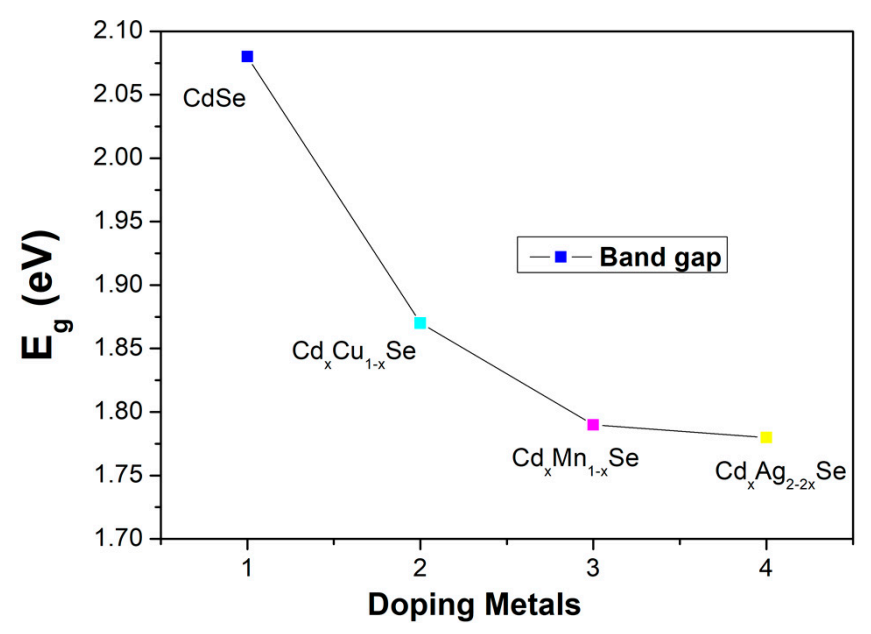

(c)

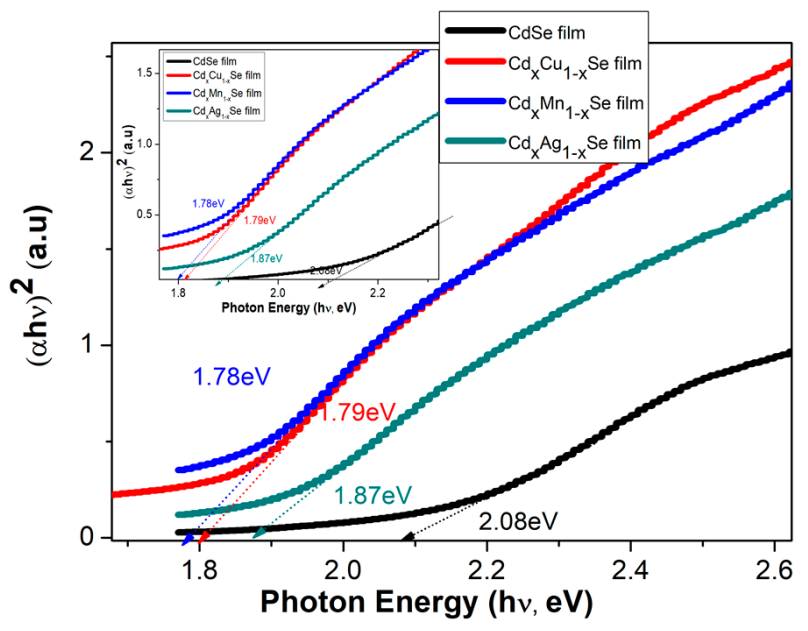

(b)

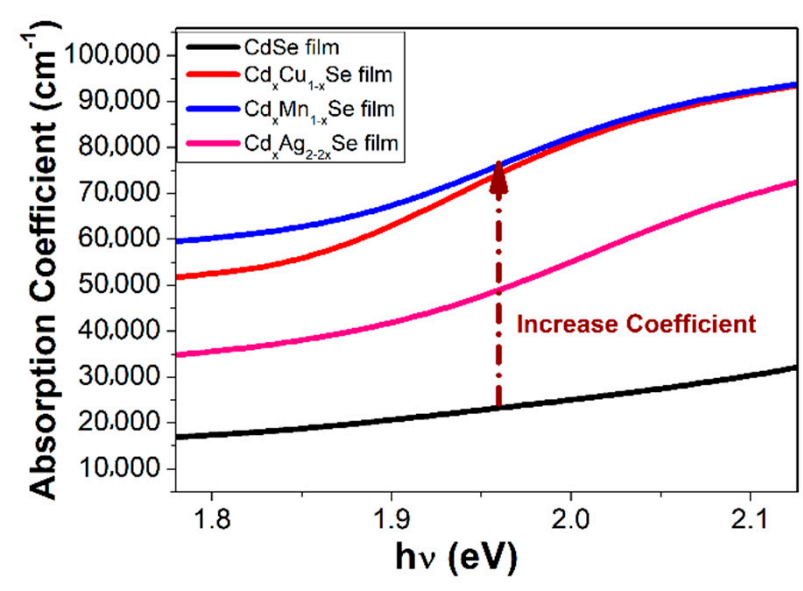

(d)

Figure 3. Variation in (a) the absorption spectra and (b) $(\alpha h v)^{2}$ plots with the changing Ag ratio and the dependence of (c) $E_{g}$ and (d) the absorption coefficient on the compositional $\mathrm{TiO}_{2} / \mathrm{CdS} / \mathrm{CdxCu}_{1-\mathrm{x}} \mathrm{Se}$, and $\mathrm{TiO}_{2} / \mathrm{CdS} / \mathrm{Cd}_{\mathrm{x}} \mathrm{Mn} \mathrm{n}_{1-\mathrm{x}} \mathrm{Se}_{\text {, and }}$ $\mathrm{TiO}_{2} / \mathrm{CdS} / \mathrm{Cd}_{\mathrm{x}} \mathrm{Ag}_{2-2 \mathrm{x}}$ Se thin films.

Due to the band structure and transition energies of materials in the absorption process, the absorption coefficient is estimated using an equation correlation [19], as follows

$$
\alpha=\frac{2.3026 . A}{d}
$$

where $A$ and $d$ are the absorption density and the thickness of the film, respectively.

As can be seen in Figure 3d, $\alpha$ significantly increases after doping, and a shift in the absorption peak for CdSe doping metals compared to that without dopant occurs. This 
result, obtained from the replacement of $\mathrm{Cd}$ atoms by the metal dopants in the doped films, which induces the d-state electrons of dopant atoms, appeared in $E_{g}$ of CdSe QDs to introduce the energy levels of dopant in the $E_{g}$ of CdSe QDs. Therefore, the absorption coefficient of the doped films was enhanced significantly because the appearance of the transition energy levels ensured that a large number of photons was absorbed in different regions [20,21].

To correlate the localized states with the $E_{g}$ of the films, the Urbach energy $\left(E_{u}\right)$ of the films was determined as follows [22]

$$
\alpha=\alpha_{o} \exp \left(\frac{h v}{E_{u}}\right)
$$

The Urbach plots between $\ln (\alpha)$ and $h v$ and $E_{u}$ (which are estimated from the slope of the curves between $\ln (\alpha)$ and $h v$ ) are shown in Figure 4. As is evident, the valuable $E_{u}$ depends on the type of doping metal. There was a minor decrease in its $E_{u}$, from $0.786 \mathrm{eV}$ (undoped film) to $2.33 \mathrm{eV}$ (doped films), due to the reduced defect states in the $\mathrm{TiO}_{2} / \mathrm{CdS} / \mathrm{Cd}_{\mathrm{x}} \mathrm{Cu}_{1-\mathrm{x}} \mathrm{Se}, \mathrm{TiO}_{2} / \mathrm{CdS} / \mathrm{Cd}_{\mathrm{x}} \mathrm{Mn}_{1-\mathrm{x}} \mathrm{Se}$, and $\mathrm{TiO}_{2} / \mathrm{CdS} / \mathrm{Cd}_{\mathrm{x}} \mathrm{Ag}_{2-2 \mathrm{x}} \mathrm{Se}$ films [23]. The $E_{u}$ value of $2.33 \mathrm{eV}$ was achieved for $\mathrm{Cu}$ doping, and was approximately two times higher than the band tail energy values for Mn and Ag doping (shown in Table 1). This implies that the large defect states in the films are a result of the unsatisfied bond, and the center of those defect states in $E_{g}$ of the $\mathrm{TiO}_{2} / \mathrm{CdS} / \mathrm{Cd}_{\mathrm{x}} \mathrm{Cu}_{1-x} \mathrm{Se}, \mathrm{TiO}_{2} / \mathrm{CdS} / \mathrm{Cd}_{x} \mathrm{Mn}_{1-x} \mathrm{Se}$, and $\mathrm{TiO}_{2} / \mathrm{CdS} / \mathrm{Cd}_{x} \mathrm{Ag}_{2-2 x} \mathrm{Se}$ films. Depending on the dopant, the defect state center can appear in the middle of $E_{g}$, near the $V B$, or near the $C B$ [24].

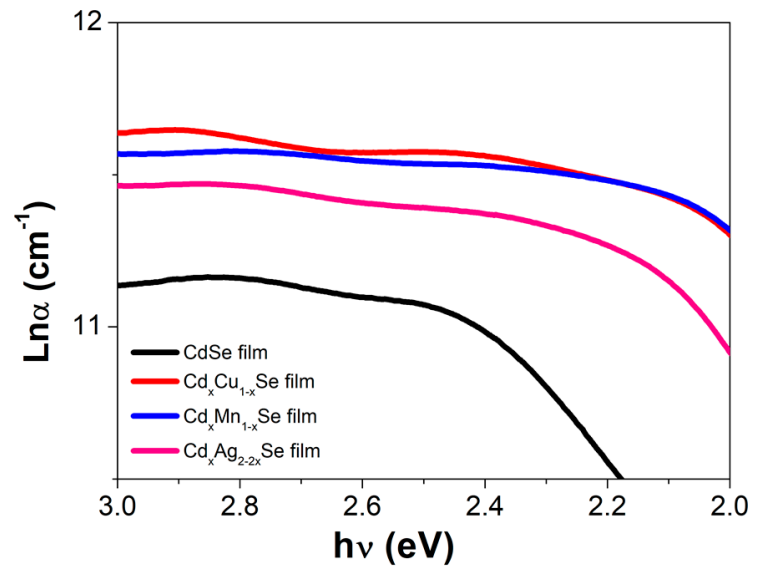

(a)

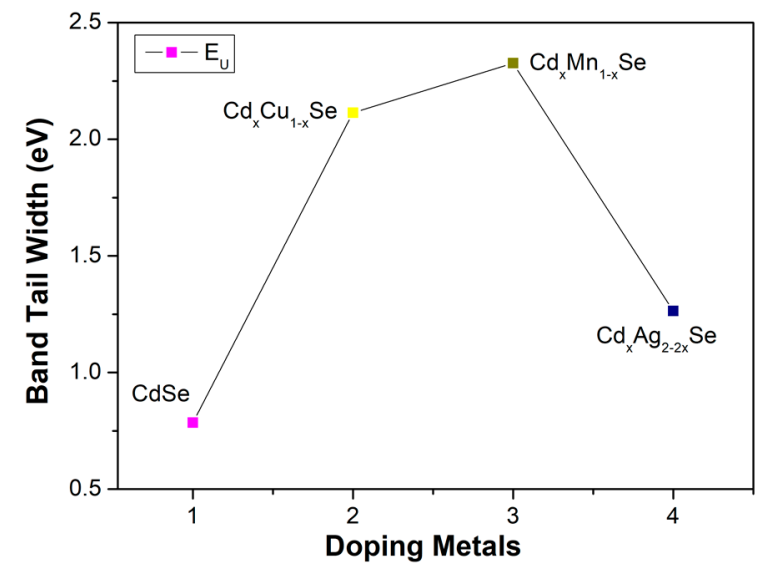

(b)

Figure 4. The dependence of (a) the $\ln (\alpha)$ of the films and (b) the Band tail energy on the compositional $\mathrm{TiO}_{2} / \mathrm{CdS} / \mathrm{CdxCu}_{1-\mathrm{x}} \mathrm{Se}_{\text {, }}$ and $\mathrm{TiO}_{2} / \mathrm{CdS} / \mathrm{Cd}_{\mathrm{x}} \mathrm{Mn}_{1-\mathrm{x}}$ Se and $\mathrm{TiO}_{2} / \mathrm{CdS} / \mathrm{Cd}_{\mathrm{x}} \mathrm{Ag}_{2-2 \mathrm{x}}$ Se thin films.

The absorption spectrum of the photovoltaic cells depends on several factors, such as the type of doping material, doping concentration, photoconductivity, thickness of the film, and especially, photon absorption in film. The steepness parameter, $\sigma$, is considered to result from the electron-phonon interaction $\left(E_{e-p}\right) . \sigma$ is correlated with $E_{e-p}$ via the following correlation: $E_{e-p}=3 / 2 \sigma$. Figure 5 and Table 1 show the variations in $\sigma$ and $E_{e-p}$, respectively. As can be seen in Figure $4 a, \sigma$ shows a downward trend as the concentration of the doping metal reduced to a minimum of $3 \%(0.011 \mathrm{eV})$, which implies a stronger electronphonon interaction energy corresponding to the $\mathrm{TiO}_{2} / \mathrm{CdS} / \mathrm{Cd}_{\mathrm{x}} \mathrm{Cu}_{1-\mathrm{x}} \mathrm{Se}$ film as a result, confirming that the bond energy is as a parameter of film composition [24]. Furthermore, the $E_{e-p}$ value for the $\mathrm{TiO}_{2} / \mathrm{CdS} / \mathrm{Cd}_{\mathrm{x}} \mathrm{Cu}_{1-\mathrm{x}} \mathrm{Se}$ film $(59.97 \mathrm{eV})$ is significantly higher than for the $\mathrm{TiO}_{2} / \mathrm{CdS} / \mathrm{Cd}_{x} \mathrm{Ag}_{2-2 x} \mathrm{Se}$ film $(32.6 \mathrm{eV})$ or the CdSe film $(20.25 \mathrm{eV})$, and $\sigma$ increases considerably. Evidently, the compositional variations in ternary $\mathrm{TiO}_{2} / \mathrm{CdS} / \mathrm{Cd}_{x} \mathrm{Cu}_{1-x} \mathrm{Se}$, 
$\mathrm{TiO}_{2} / \mathrm{CdS} / \mathrm{Cd}_{\mathrm{x}} \mathrm{Mn}_{1-\mathrm{x}} \mathrm{Se}$, and $\mathrm{TiO}_{2} / \mathrm{CdS} / \mathrm{Cd}_{\mathrm{x}} \mathrm{Ag}_{2-2 \mathrm{x}} \mathrm{Se}$ thin films caused variations in the optical parameters [24].

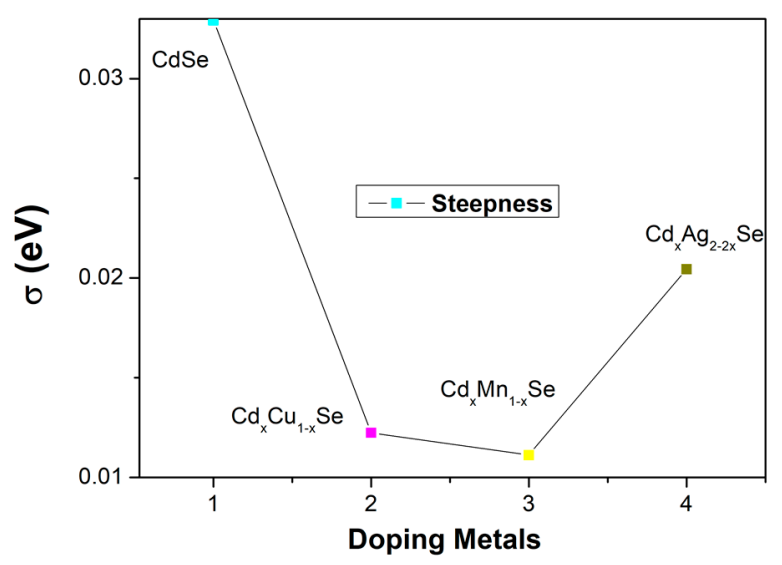

(a)

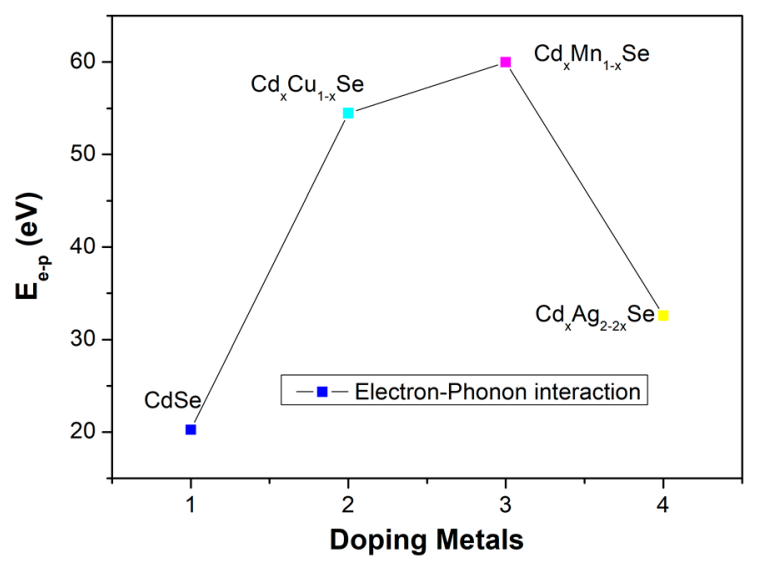

(b)

Figure 5. The dependence of (a) $\sigma$ and (b) $E_{\mathrm{e}-\mathrm{p}}$ in metal addition in films.

\subsection{Electrical Properties}

In this section, we study the current-voltage (J-V) characteristics of QDSSCs and, subsequently, the estimated primary physical parameters using one illuminated J-V curve. The photovoltaic device significantly depends on the four resistances in a photovoltaic cell: an external resistance $\left(R_{D}\right)$, internal resistance $\left(R_{d}\right)$, series resistance $\left(R_{s}\right)$, and a shunt resistance $\left(R_{S H}\right)$ (Figure 6). Ideally, $R_{\mathrm{S}}$ should be zero, and $R_{S H}$ should be infinite. As a result of the dynamic parameters, significant power losses caused by the dynamic resistances due to various factors, such as manufacturing defects, technological processes, and natural materials, are estimated.

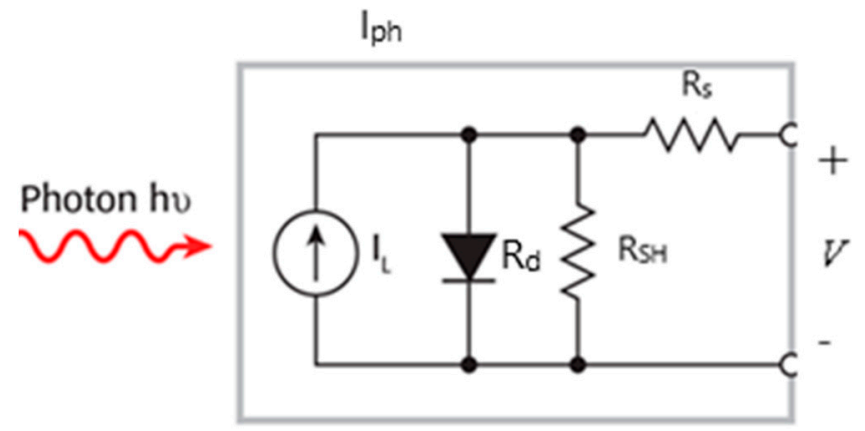

Figure 6. The circuit of a photovoltaic cell [25].

In [26], we conducted the equations for dynamic parameters as follows

$$
\begin{gathered}
R_{D}=\frac{V_{1}-V_{2}}{I_{2}-I_{1}} \\
R_{d}=\frac{1}{\alpha\left(I_{2}-I_{1}\right)} \operatorname{Ln}\left(\frac{I_{p h}+I_{o}-I_{1}}{I_{p h}+I_{o}-I_{2}}\right) \\
R_{S}=R_{D}-R_{d} \\
R_{S H}=\frac{V_{O C}}{I_{p h}-I_{o}\left(e^{\left.\alpha V_{O C}-1\right)}\right.} \\
\alpha=\frac{q}{n k_{B} T}
\end{gathered}
$$


where $q$ and $k_{B}$ are the electronic charge and Boltzmann constant, respectively, $T$ is the room temperature, $I_{p h}$ is the incident light intensity, and $I_{0}$ is the diode saturation current. The obtained physical parameters are listed in Table 2.

Table 2. The values of the performance efficiency (efficiency, short-circuit current, open-circuit voltage, fill factor) and $R_{D}$, $R_{d}, R_{S H}, R_{S}$ were estimated from J-V curves and $R_{c t 1}, R_{c t 2}$ were obtained from the EIS experiment.

\begin{tabular}{|c|c|c|c|c|c|c|c|c|c|c|}
\hline Atom $\%$ & $\begin{array}{c}J_{\mathrm{SC}} \\
\left(\mathrm{mA} / \mathrm{cm}^{2}\right)\end{array}$ & FF & $\begin{array}{l}V_{O C} \\
\text { (V) }\end{array}$ & $\eta(\%)$ & $\begin{array}{l}R_{D} \\
(\Omega)\end{array}$ & $\begin{array}{l}R_{d} \\
(\Omega)\end{array}$ & $\begin{array}{c}R_{S H} \\
(\mathrm{k} \Omega)\end{array}$ & $\begin{array}{l}R_{S} \\
(\Omega)\end{array}$ & $\begin{array}{l}R_{c t 1} \\
(\Omega)\end{array}$ & $\begin{array}{l}R_{c t 2} \\
(\Omega)\end{array}$ \\
\hline CdSe film & 12.4 & 0.379 & 0.42 & $1.97 \pm 0.01$ & 33.75 & 96.5 & 12.4 & 62.8 & 629 & 193 \\
\hline $\mathrm{Cd}_{\mathrm{x}} \mathrm{Cu}_{1-\mathrm{x}}$ Se film & 19.89 & 0.419 & 0.505 & $4.24 \pm 0.003$ & 25.31 & 61 & 19.9 & 35.7 & 255 & 21 \\
\hline $\mathrm{Cd}_{\mathrm{x}} \mathrm{Mn}_{1-\mathrm{x}}$ Se film & 18.99 & 0.381 & 0.52 & $3.9 \pm 0.005$ & 27.51 & 64.1 & 18.99 & 36.6 & 205 & 25 \\
\hline $\mathrm{Cd}_{x} \mathrm{Ag}_{2-2 \mathrm{x}}$ Se film & 11 & 0.53 & 0.47 & $2.75 \pm 0.008$ & 41.81 & 108 & 10.92 & 66.2 & 256 & 23 \\
\hline
\end{tabular}

In this experiment, samples of photovoltaic cells fabricated using the $\mathrm{TiO}_{2} / \mathrm{CdS} / \mathrm{Cd}_{x}$ $\mathrm{Cu}_{1-x} \mathrm{Se}, \mathrm{TiO}_{2} / \mathrm{CdS} / \mathrm{Cd}_{\mathrm{x}} \mathrm{Mn}_{1-\mathrm{x}} \mathrm{Se}$, and $\mathrm{TiO}_{2} / \mathrm{CdS} / \mathrm{Cd}_{\mathrm{x}} \mathrm{Ag}_{2-2 \mathrm{x}}$ Se photoanodes were recorded by a Keithley 2400 source meter under identical illumination condition. Figure 7a,b show the graphical representation of the measurement results. The performance efficiency of the photovoltaic cells is sensitive to the concentration of the metal dopants (Figure 6). For example, the energy conversion value increased significantly from $1.97 \%$ (undoped film) to $4.24 \%\left(\mathrm{TiO}_{2} / \mathrm{CdS} / \mathrm{Cd}_{\mathrm{x}} \mathrm{Cu}_{1-\mathrm{x}} \mathrm{Se}\right.$ film), and the highest efficiency was obtained for $\mathrm{Cu}$ doping. Furthermore, the efficiency dropped to $2.75 \%$ (for $\mathrm{TiO}_{2} / \mathrm{CdS} / \mathrm{Cd}_{x} \mathrm{Ag}_{2-2 \mathrm{x}} \mathrm{Se}$ film). Furthermore, the valuation parameters of the photovoltaic cells were significantly influenced by doping metals; the corresponding experimental values are recorded in Table 2.

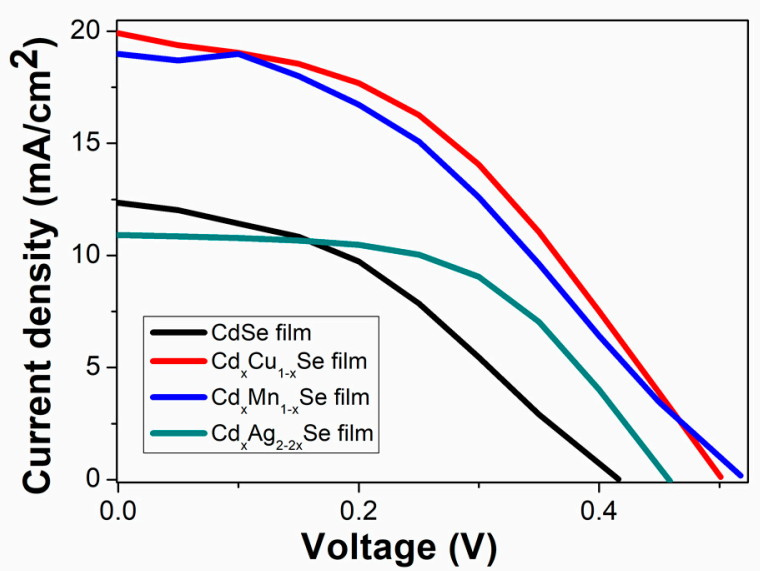

(a)

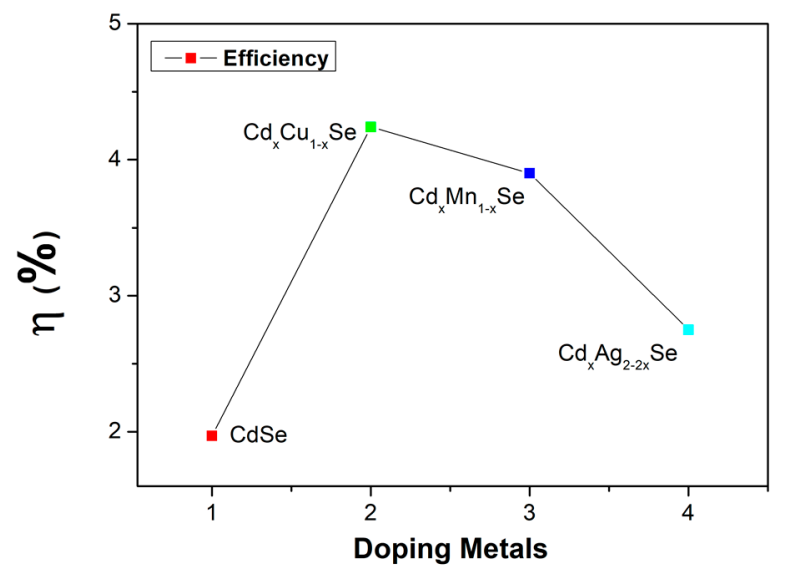

(b)

Figure 7. (a) Variation of photocurrent density-voltage curves and (b) dependence of the performance efficiency on metal addition in films.

The values of the $R_{D}, R_{d}$, and $R_{S H}$ of the photovoltaic cells are extracted from the photocurrent density curves in Figure $8 \mathrm{a}-\mathrm{c}$, and one J-V curve method, and listed in Table 2. Moreover, $R_{S}$ is the resistance between the external circuit and the counter electrode photoanode. Generally, $R_{S}$ drops rapidly with the doping of metal dopants because of the difference between $R_{D}$ and $R_{d}$ value of $R_{S}$ decreased from $62.8 \Omega$ (undoped film) to $35.7 \Omega\left(\mathrm{TiO}_{2} / \mathrm{CdS} / \mathrm{Cd}_{\mathrm{x}} \mathrm{Cu}_{1-\mathrm{x}}\right.$ Se film). Here, $R_{D}$ is the resultant of $R_{S H}, R_{d}$ (through the diode), and $R_{S}$. The value of $R_{D}$ was lowest for the $\mathrm{TiO}_{2} / \mathrm{CdS} / \mathrm{Cd}_{\mathrm{x}} \mathrm{Cu}_{1-\mathrm{x}}$ Se film, and increased to attain $66.2 \Omega$ for the $\mathrm{TiO}_{2} / \mathrm{CdS} / \mathrm{Cd}_{x} \mathrm{Ag}_{2-2 \mathrm{x}}$ Se film. Generally, the value of $R_{D}$ of the doped films is lower than that of the undoped film because the replacement of the $\mathrm{Cd}$ atoms in the CdSe film hosted by the metal dopants reduced resistance inside each layer and at multilayer surfaces. Moreover, a leakage current generated in the technology process can change $R_{D}$. Therefore, while $R_{S H}$ should be infinite for an ideal photovoltaic 
cell, practically, there is an upper limit of $20 \mathrm{k} \Omega$ for $R_{S H}$. According to Table 2, the $R_{S H}$ values for doped films are higher without dopant, and the highest, $19.9 \mathrm{k} \Omega$, is obtained from the $\mathrm{TiO}_{2} / \mathrm{CdS} / \mathrm{Cd}_{\mathrm{x}} \mathrm{Cu}_{1-\mathrm{x}} \mathrm{Se}$ film. Evidently, $R_{S H}$ is sensitive to the doping metal; while, for $C$ doping, $R_{S H}$ reaches a maximum value of $19.9 \mathrm{k} \Omega$, for Ag doping, $R_{S H}$ value decreased to $10.92 \mathrm{k} \Omega$ for $\mathrm{TiO}_{2} / \mathrm{CdS} / \mathrm{Cd}_{\mathrm{x}} \mathrm{Ag}_{2-2 \mathrm{x}} \mathrm{Se}$ film. This result was also proven as the UV-Vis peak moves to a longer wavelength owing to the reduced $E_{g}$ and enhanced $E_{e-p}$ discussed in Section 3.2. Furthermore, our result also agrees with reference [26].

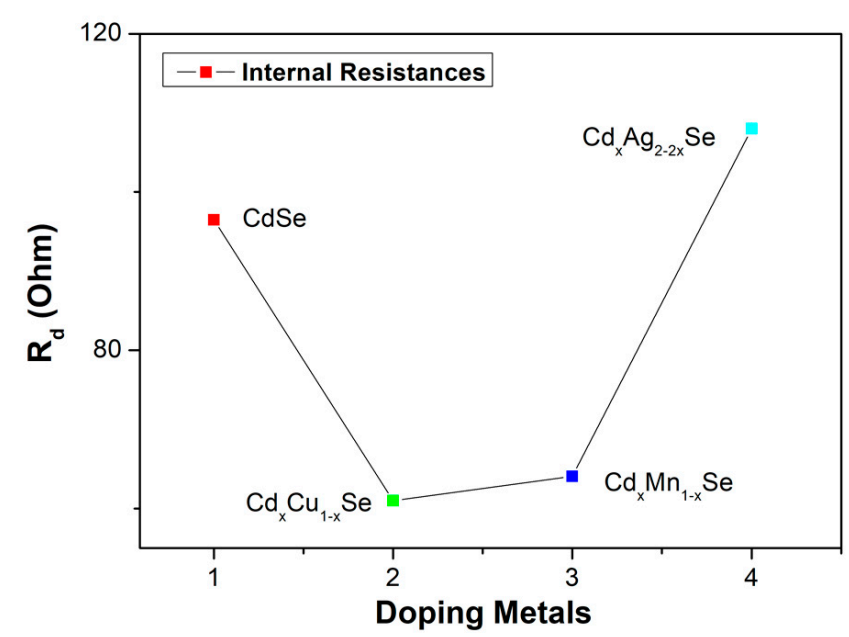

(a)

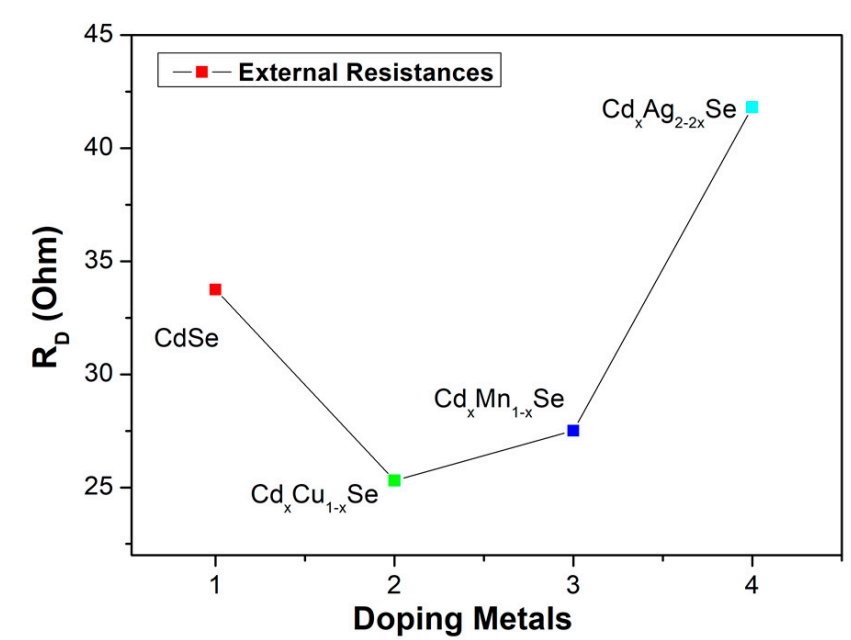

(b)

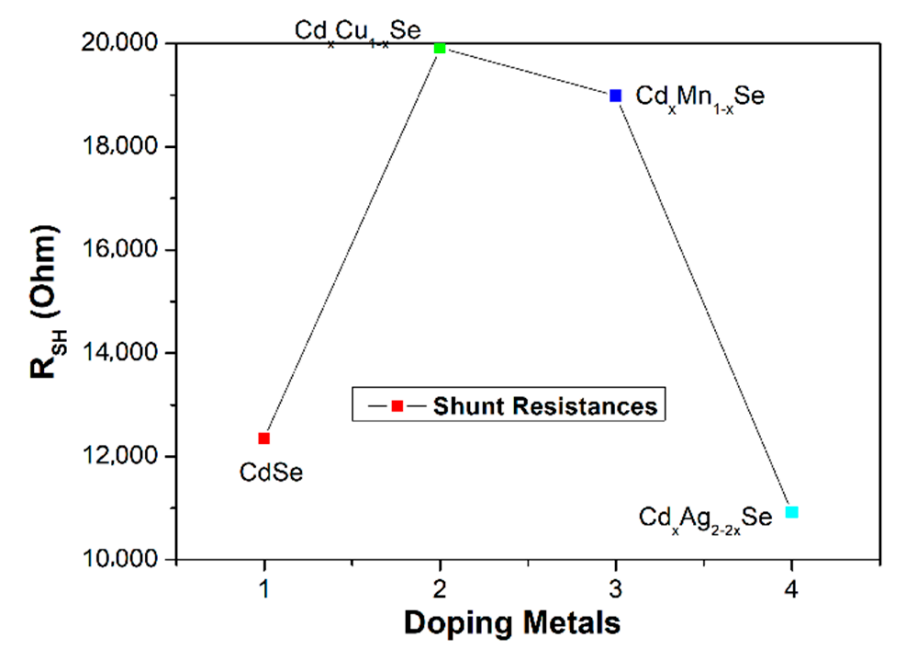

(c)

Figure 8. Dependence of (a) the external resistance, (b) internal resistance, and (c) shunt resistance on metal addition in films.

Conventionally, electrochemical impedance spectroscopy (EIS) was found by MosaSero [27] to determine the occurring processes through contacts, $\mathrm{TiO}_{2}$ film and polysulfide electrolyte. These investigation and analysis processes included several steps, such as the pumping of excited charges from the $C B$ of QDs to the $C B$ of $\mathrm{TiO}_{2}$, diffusive charges inside the $\mathrm{TiO}_{2}$ film before moving to the external circuit, the transfer of electrons to the counter electrode/polysulfide. In this case, an equivalent circuit was extracted from the EIS fitting using the Nova software. As far as the EIS fitting is concerned, the equivalent circuits for simulation were chosen for a consistent match between the EIS experiment and EIS fitting. Subsequently, $R_{c t 1}$ and $R_{c t 2}$ were obtained from EIS fitting. Those values are listed in Table 2.

Figure 9a-c shows the EIS curves of the photovoltaic cells based on the metal dopants, and dynamic resistance curves in the counter electrode/polysulfide electrolyte surface, and in the redox process of electrolysis, $R_{c t 1}$, and the recombination resistance at $\mathrm{TiO}_{2} / \mathrm{QDs}$ surface, and in $\mathrm{TiO}_{2}$ film, $R_{c t 2}$. In the same way, the recombination resistances, which 
are listed in Table 2, depend significantly on the doping concentration of the metal dopants. A downward trend was observed $R_{c t 1}$ value from $629 \Omega$ (undoped film) to $205 \Omega$ $\left(\mathrm{TiO}_{2} / \mathrm{CdS} / \mathrm{Cd}_{\mathrm{x}} \mathrm{Mn}_{1-\mathrm{x}} \mathrm{Se}\right.$ film) or to $255 \Omega\left(\mathrm{TiO}_{2} / \mathrm{CdS} / \mathrm{Cd}_{\mathrm{x}} \mathrm{Cu}_{1-\mathrm{x}} \mathrm{Se}\right.$ film). The value of $R_{c t 1}$ was the lowest $(205 \Omega)$ for the $\mathrm{TiO}_{2} / \mathrm{CdS} / \mathrm{Cd}_{\mathrm{x}} \mathrm{Mn}_{1-\mathrm{x}} \mathrm{Se}$ film, and it increased to a maximum value of $256 \Omega$ for the $\mathrm{TiO}_{2} / \mathrm{CdS} / \mathrm{Cd}_{x} \mathrm{Ag}_{2-2 \mathrm{x}} \mathrm{Se}$ film. This implies that a decrease in the recombination resistance at the counter electrode/polysulfide electrolyte surface and in the redox process of the electrolyte resulted in the enhanced current density $\left(19.89 \mathrm{~mA} / \mathrm{cm}^{2}\right)$ and energy conversion (4.24\%) compared to those for the undoped film $\left(12.4 \mathrm{~mA} / \mathrm{cm}^{2}\right.$ and $1.97 \%$, respectively) [28]. Furthermore, as mentioned above, the correlation with $R_{c t 2}$ caused the recombination resistance in the photovoltaic cells, which indicates that the recombination processes at $\mathrm{TiO}_{2} / \mathrm{QDs}$ surface, inside QDs, and the diffusion of charges in $\mathrm{TiO}_{2}$ film were correlated to the $\mathrm{TiO}_{2} / \mathrm{CdS} / \mathrm{Cd}_{\mathrm{x}} \mathrm{Cu}_{1-\mathrm{x}} \mathrm{Se}$ film, $\mathrm{TiO}_{2} / \mathrm{CdS} / \mathrm{Cd}_{\mathrm{x}} \mathrm{Mn}_{1-\mathrm{x}} \mathrm{Se}$ film, and $\mathrm{TiO}_{2} / \mathrm{CdS} / \mathrm{Cd}_{x} \mathrm{Ag}_{2-2 x} \mathrm{Se}$ film. Therefore, $R_{c t 2}$ is pivotal in explaining the enhanced current density and performance efficiency after the proposed metal doping. Correspondingly, the values of the $R_{c t 2}$ decreased from $193 \Omega$ (undoped film) to $21 \Omega$ (Cu doping). The value of $R_{c t 2}$ was the lowest for $\mathrm{Cu}$ doping $(21 \Omega)$, and increased to a maximum of $23 \Omega$ for Ag doping. This result is consistent with the results from the photocurrent density curve, absorption spectra, and the band tail energy. Because of the reduced recombination resistance, a large number of charges accumulated, further reducing the recombination process of the excited electrons with the surface states of QDs, resulting in the fast pumping of excited charges between $\mathrm{CdS}, \mathrm{CdSe}$ and $\mathrm{TiO}_{2}$ [29].

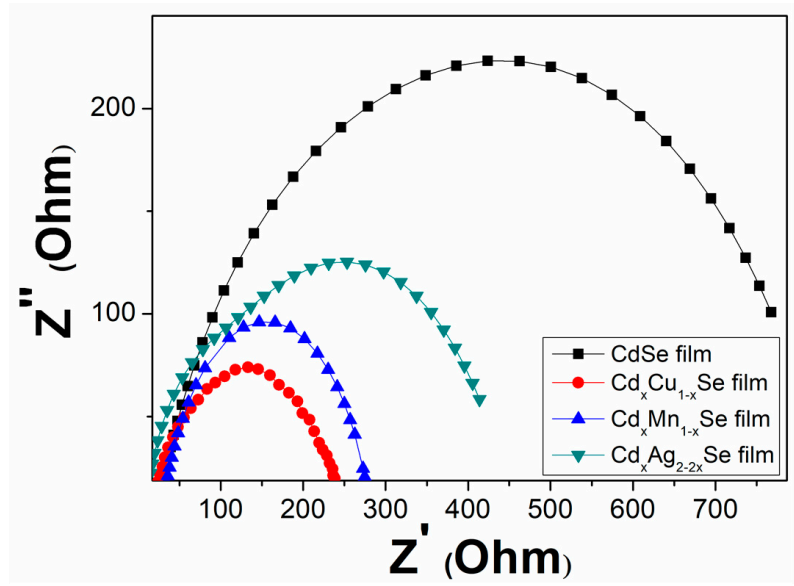

(a)

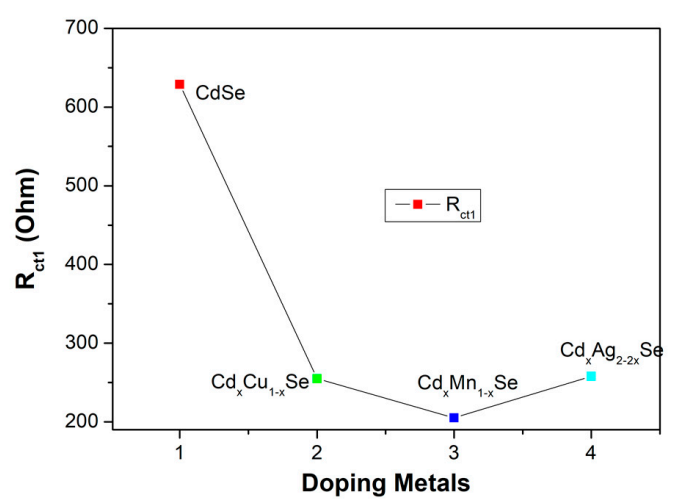

(b)

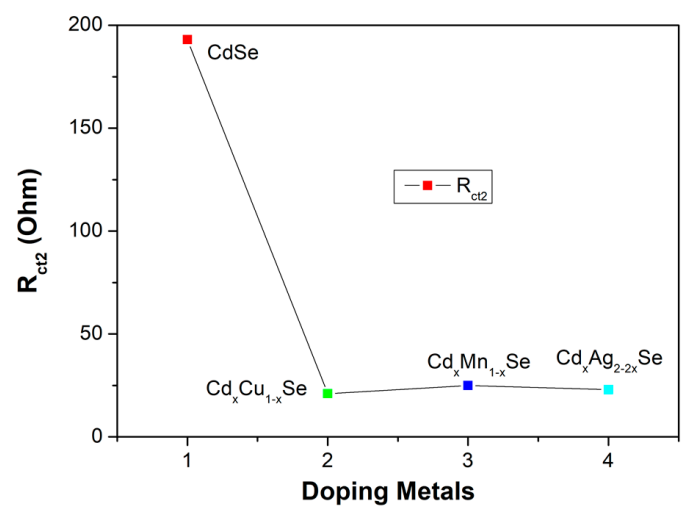

(c)

Figure 9. (a) Variation of the Electrochemical Impedance Spectra and (b) dependence of the recombination resistances: (b) polyelectrolyte and polyelectrolyte/counter electrode contact $\left(R_{c t 1}\right)$ and (c) $\mathrm{TiO}_{2} / \mathrm{QDs}$ contact and diffusion resistance in $\mathrm{TiO}_{2}$ films $\left(R_{c t 2}\right)$. 


\section{Experiment}

3.1. Materials

TEC7 Glass Plates $3.2 \mathrm{~mm}\left(2.2 \mathrm{~mm}\right.$ of thickness, $1.2 \times 2 \mathrm{~cm}=0.196 \mathrm{~cm}^{2}$ of area) was purchased from Sigma in Frankfurter, German. Titania paste, Sodium Selenite $\left(\mathrm{Na}_{2} \mathrm{SeO}_{3}\right)$, $\mathrm{Cd}\left(\mathrm{NO}_{3}\right)_{2} .2 \mathrm{H}_{2} \mathrm{O}, \mathrm{Na}_{2} \mathrm{~S} .9 \mathrm{H}_{2} \mathrm{O}, \mathrm{Cu}\left(\mathrm{NO}_{3}\right)_{2} .3 \mathrm{H}_{2} \mathrm{O}, \mathrm{Mn}\left(\mathrm{CH}_{3} \mathrm{COO}\right)_{2} \cdot 4 \mathrm{H}_{2} \mathrm{O}, \mathrm{AgNO}_{3}, \mathrm{Na}_{2} \mathrm{SO}_{3}$, $\mathrm{NaOH}$, Se powder, $\mathrm{KCl}, \mathrm{Na}_{2} \mathrm{~S}, \mathrm{~S}$ were bought from Sigma in Frankfurter, German. All chemicals were used directly without further purification.

\subsection{Preparation Processes}

$\mathrm{TiO}_{2}$ film was coated on the Fluorine-doped tin oxide (FTO) followed by annealing in air at $500{ }^{\circ} \mathrm{C}$.

Fabrication of CdS film: The FTO/ $\mathrm{TiO}_{2}$ film was dipped in $\mathrm{Cd}^{2+}$-solution $(2.665 \mathrm{~g}$ $\mathrm{Cd}\left(\mathrm{NO}_{3}\right)_{2} \cdot 2 \mathrm{H}_{2} \mathrm{O}$ dissolved in a $20 \mathrm{~mL}$ mixture of ethanol and pure water in 1:1 ratio) for $5 \mathrm{~min}$, and then washed with ethanol. Furthermore, it was dipped in $\mathrm{S}^{2-}$ solution $(12 \mathrm{~g}$ of $\mathrm{Na}_{2} \mathrm{~S} .9 \mathrm{H}_{2} \mathrm{O}$, dissolved in $100 \mathrm{~mL}$ mixture of methanol and pure water in 1:1 ratio) for $5 \mathrm{~min}$ and then washed with methanol. This two-step process formed a single layer of the CdS film. Two layers of the CdS film were coated by repeating the two-step process.

Fabrication of $\mathrm{Cu}^{2+}$ Doped, $\mathrm{Mn}^{2+}$ Doped, and $\mathrm{Ag}^{+}$Doped CdSe Films

For $\mathrm{Cu}^{2+}$ doping, $\mathrm{Cd}^{2+}$ and $\mathrm{Cu}^{2+}$-solution $\left(0.1 \mathrm{MCd}\left(\mathrm{NO}_{3}\right)_{2} \cdot 2 \mathrm{H}_{2} \mathrm{O}\right.$ and $0.1 \mathrm{MCu}\left(\mathrm{NO}_{3}\right)_{2} \cdot 3 \mathrm{H}_{2} \mathrm{O}$ dissolved in a $30 \mathrm{~mL}$ mixture of ethanol and pure water in 1:1 ratio) was kept for $5 \mathrm{~min}$, and then washed with ethanol.

For $\mathrm{Mn}^{2+}$ doping, $\mathrm{Cd}^{2+}$ and $\mathrm{Mn}^{2+}$-solution $\left(0.1 \mathrm{M} \mathrm{Cd}\left(\mathrm{NO}_{3}\right)_{2} . \quad 2 \mathrm{H}_{2} \mathrm{O}\right.$ and $0.1 \mathrm{M}$ $\mathrm{Mn}\left(\mathrm{CH}_{3} \mathrm{COO}\right)_{2} .4 \mathrm{H}_{2} \mathrm{O}$ dissolved in $30 \mathrm{~mL}$ mixture of methanol and pure water in 1:1 ratio) was kept for $5 \mathrm{~min}$, and then washed with methanol.

For $\mathrm{Ag}^{+}$doping, $\mathrm{Cd}^{2+}$ and $\mathrm{Ag}^{+}$-solution $\left(0.1 \mathrm{M} \mathrm{Cd}\left(\mathrm{NO}_{3}\right)_{2} .2 \mathrm{H}_{2} \mathrm{O}\right.$ and $0.1 \mathrm{M} \mathrm{AgNO}_{3}$ dissolved in a $30 \mathrm{~mL}$ mixture of ethanol and pure water in 1:1 ratio) was kept for $5 \mathrm{~min}$, and then washed with ethanol.

Furthermore, for the fabrication of $\mathrm{Cu}^{2+}, \mathrm{Mn}^{2+}$, and $\mathrm{Ag}^{+}$doped films, the previously synthesized $\mathrm{FTO} / \mathrm{TiO}_{2} / \mathrm{CdS}$ were, respectively, separately dipped into the solutions mentioned above. Subsequently, the films were dipped in $\mathrm{Se}^{2-}$-solution $(2.27 \mathrm{~g}$ Se powder and $0.6 \mathrm{M} \mathrm{Na}_{2} \mathrm{SO}_{3}$ were dissolved in $100 \mathrm{~mL}$ of water and then added to $5 \mathrm{~mL}$ of $1 \mathrm{M} \mathrm{NaOH}$. Furthermore, the solution was stored at $70{ }^{\circ} \mathrm{C}$ in $7 \mathrm{~h}$ ) for $15 \mathrm{~min}$ at $50{ }^{\circ} \mathrm{C}$, and then washed with pure water to form a single layer of the CdSe film desired doping material. Three layers of the CdSe film with the desired doping material were coated by repeating the above process. Finally, the films were annealed in the range from $120^{\circ} \mathrm{C}$ to $300{ }^{\circ} \mathrm{C}$ as in vacuum for $30 \mathrm{~min}$.

The polysulfide electrolyte was prepared by mixing $0.5 \mathrm{M} \mathrm{Na}_{2} \mathrm{~S}, 0.2 \mathrm{M} \mathrm{S}$, and $0.2 \mathrm{M}$ $\mathrm{KCl}$ in pure water in 7:3 ratio.

The photoanodes have been synthesized and characterized using XRD (Philips, PANalytical $X^{\prime}$ Pert, $\mathrm{CuK} \alpha$ radiation). The absorption spectra were recorded using a UV-Vis JASCO V-670. The completed photovoltaic cells were characterized using a Keithley 2400 source meter developed by SOLARENA, Sweden. The obtained J-V curves are supported to estimate the valuable electrical range of devices. The scanning speed voltage of the equipment was set at $5 \mathrm{mV} / \mathrm{s}$ in the range from $V_{O C}$ to 0 . The electrochemical impedance spectroscopy was performed using an impedance analyzer (ZAHNER CIMPS).

\section{Conclusions}

$\mathrm{TiO}_{2} / \mathrm{CdS} / \mathrm{Cd}_{\mathrm{x}} \mathrm{Cu}_{1-\mathrm{x}} \mathrm{Se}, \mathrm{TiO}_{2} / \mathrm{CdS} / \mathrm{Cd}_{\mathrm{x}} \mathrm{Mn}_{1-\mathrm{x}} \mathrm{Se}$, and $\mathrm{TiO}_{2} / \mathrm{CdS} / \mathrm{Cd}_{\mathrm{x}} \mathrm{Ag}_{2-2 \mathrm{x}} \mathrm{Se}$ thin films were successfully synthesized on FTO glass as photoanodes in solar cells, which were sensitive to $\mathrm{Cu}_{2} \mathrm{~S}$ counter electrode. The QDSSCs using the $\mathrm{TiO}_{2} / \mathrm{CdS} / \mathrm{Cd}_{\mathrm{x}} \mathrm{Cu}_{1-\mathrm{x}} \mathrm{Se}$ photoanode exhibits the highest performance: $J_{\mathrm{SC}}=19.89 \mathrm{~mA} / \mathrm{cm}^{2}, V_{\mathrm{OC}}=0.505 \mathrm{~V}, F F=0.379$, and $\eta=4.24 \%$ as a result of enhancing electrocatalytic activity, charge transfer and charge collection, reducing recombination, and the longer excited electron lifetime. The optical 
parameters also are sensitive to dopant. This implies that large defect states in the films are a result of the unsatisfied bond and the center of those defect states in $E_{g}$ of $\mathrm{Cd}_{\mathrm{x}} \mathrm{Cu}_{1-\mathrm{x}} \mathrm{Se}$ films. They can be seen in the middle of $E_{g}$, near the $V B$, or near the $C B$. Furthermore, the electrical properties of the $\mathrm{Cd}_{\mathrm{x}} \mathrm{Cu}_{1-\mathrm{x}}$ Se were also investigated through the $R_{S}, R_{S H}$ dynamic resistance, recombination resistance, diffusion resistance in $\mathrm{TiO}_{2}$ layer, and $\mathrm{TiO}_{2} / Q D$, $R_{c t 1}, R_{c t 2}$. As a result, the recombination and dynamic resistance of $\mathrm{TiO}_{2} / \mathrm{QDs}$ and diffusion in $\mathrm{TiO}_{2}\left(R_{c t 2}\right)$ films, and the diffusion at the counter electrode/electrolyte $\left(R_{c t 1}\right)$, decreased significantly.

Author Contributions: Conceptualization, D.H.P. and H.T.T.; methodology, D.H.P. and H.T.T.; formal analysis, D.H.P., H.T.T., V.-C.N. and M.H.N.T.; in-vestigation, D.H.P. and H.T.T.; data curation, D.H.P. and H.T.T.; writing-original draft preparation, D.H.P. and H.T.T.; writing-review and editing, D.H.P., H.T.T., V.-C.N. and M.H.N.T.; funding acquisition, D.H.P. and H.T.T. All authors have read and agreed to the published version of the manuscript.

Funding: This research is supported by Industrial University of Ho Chi Minh City (IUH) under grant number 112/HD-DHCN.

Institutional Review Board Statement: Not applicable.

Informed Consent Statement: Not applicable.

Data Availability Statement: The data presented in this study are available on request from the corresponding author.

Conflicts of Interest: The authors declare no competing interests.

\section{References}

1. Chattopadhyay, S.; Sen, P.; Andrews, J.T.; Sen, P.K. Semiconductor core-shell quantum dot: A low temperature nano-sensor material. J. Appl. Phys. 2012, 111, 034310. [CrossRef]

2. Ariful, A.; He, T.; Eid, K.; Abdullah, A.M.; Curry, M.L.; Du, A.; Puente Santiago, A.R.; Echegoyen, L.; Noveron, J.C. Tuning the Intermolecular Electron Transfer of Low-Dimensional and Metal-Free BCN/C60 Electrocatalysts via Interfacial Defects for Efficient Hydrogen and Oxygen Electrochemistry. J. Am. Chem. Soc. 2021, 143, 1203-1215.

3. Sanchez-Ramirez, E.A.; Hernandez-Perez, M.A.; Aguilar-Hernandez, J.; Rangel-Salinas, E. Nanocrystalline $\mathrm{CdS}_{1-\mathrm{x}} \mathrm{Se}_{\mathrm{x}}$ alloys as thin films prepared by chemical bath deposition: Effect of $x$ on the structural and optical properties. J. Alloys Compd. 2014, 615, 511-514. [CrossRef]

4. Husain, M.; Pal Singh, B.; Kumar, S.; Sharma, T.P.; Sebastian, P.J. Optical, electrical and structural investigations on Cd ${ }_{1-x} Z n_{x} S e$ sintered films for photovoltaic applications. Sol. Energy Mater. Sol. Cells 2003, 76, 399-415. [CrossRef]

5. Sanchez-Ramirez, E.A.; Hernandez-Perez, M.A.; Aguilar-Hernandez, J.R. Study on the introduction of Se into CdS thin films: Influence on the kinetics of the deposition and the structural and optical properties. Appl. Surf. Sci. 2015, 347, 35-39. [CrossRef]

6. Shockley, W.; Queisser, H.J. Detailed balance limit of efficiency of p-n junction solar cells. J. Appl. Phys. 1961, 32, 510-519. [CrossRef]

7. Hagfeldt, A.; Boschloo, G.; Sun, L.; Kloo, L.; Pettersson, H. Dye-sensitized solar cells. Chem. Rev. 2010, 110, 6595-6663. [CrossRef] [PubMed]

8. Phuc, D.H.; Tung, H.T. Band tunable CdSe quantum dot-doped metals for quantum dot-sensitized solar cell application. Int. J. Photoenergy 2019, 2019, 9812719. [CrossRef]

9. Wang, P.; Abrusci, A.; Wong, H.M.P.; Svensson, M.; Anderson, M.R.; Greenham, N.C. Photoinduced charge transfer and efficient solar energy conversion in a blend of a red polyfluorene copolymer with CdSe nanoparticles. Nano Lett. 2006, 6, 1789-1793. [CrossRef]

10. Fan, S.-Q.; Fang, B.; Kim, J.H.; Jeong, B.; Kim, C.; Yu, J.-S.; Ko, J. Ordered multimodal porous carbon as highly efficient counter electrodes in dye-sensitized and quantum-dot solar cells. Langmuir 2010, 26, 13644-13649. [CrossRef] [PubMed]

11. Fan, S.-Q.; Cao, R.-J.; Xi, Y.-X.; Gao, M.; Wang, M.-D.; Kim, D.-H.; Kim, C.-W.; Ko, J.-J. CdSe quantum dots as co-sensitizers of organic dyes in solar cells for red-shifted light harvesting. Optoelectron. Adv. Mater. Rapid Commun. 2009, 3, $1027-1033$.

12. Song, L.; Duan, J.; Zhan, J. One-pot Microwave Assisted Synthesis of Homogeneously Alloyed CdSe $\mathrm{Te}_{1-\mathrm{x}} \mathrm{Nanocrystals}_{\mathrm{s}}$ with Tunable Photoluminescence. Mater. Lett. 2010, 64, 1843-1845. [CrossRef]

13. Vogel, R.; Pohl, K.; Weller, H. Sensitization of highly porous, polycrystalline $\mathrm{TiO}_{2}$ electrodes by quantum sized CdS. Chem. Phys Lett. 1990, 174, 241-246. [CrossRef]

14. Tung, H.T.; Phuc, D.H.; Chung, N.T.K.; Thuy, N.T.N. Enhanced light absorption and charge recombination control in quantum dot sensitized solar cells using Copper and Manganese doped cadmium sulfide quantum dots. Environ. Prog. Sustain. Energy 2021, e13650. [CrossRef] 
15. Ramasamy, K.; Malik, M.A.; Helliwell, M.; Raftery, J.; O’Brien, P. Thio-and dithio-biuret precursors for zinc sulfide, cadmium sulfide, and zinc cadmium sulfide thin films. Chem. Mater. 2011, 23, 1471-1481. [CrossRef]

16. Tauc, J.; Radu, G.; Anina, V. Optical properties and electronic structure of amorphous germanium. Phys. Status Solidi 1966, 15, 627-637. [CrossRef]

17. Ha, T.T.; Chi, C.H.; Vy, N.T.; Thoa, N.T.P.; Huynh, T.D.; Lam, Q.V. Improving the performance of QDSSCs based on $\mathrm{TiO}_{2} / \mathrm{CdS}$ (Silar)/CdSe(Colloid)/Zns(Silar) photoanodes. Environ. Prog. Sustain. Energy 2015, 34, 1774-1779. [CrossRef]

18. Ueda, Y.; Ohtani, T. Mechanochemical Synthesis, Vacancy-Ordered Structures and Low-Dimensional Properties of Transition Metal Chalcogenides. Handb. Solid State Chem. 2017, 383-433. [CrossRef]

19. Al-Bataineh, Q.M.; Alsaad, A.M.; Ahmad, A.A.; Al-Sawalmih, A. Structural, electronic and optical characterization of ZnO thin film-seeded platforms for ZnO nanostructures: Sol-gel method versus ab initio calculations. J. Electron. Mater. 2019, 48, 5028-5038. [CrossRef]

20. Siddiqui, F.Y.; Shaikh, S.U.; Desale, D.J.; Upadhye, D.S.; Mahajan, S.V.; Ghule, A.V.; Varshney, P.; Han, S.-H.; Sharma, R. Band gap engineering by substitution of $\mathrm{S}$ by $\mathrm{Se}$ in nanostructured $\mathrm{CdS}_{1-\mathrm{x}} \mathrm{Se}_{\mathrm{x}}$ thin films grown by soft chemical route for photosensor application. Mater. Sci. Semicond. Process. 2014, 27, 404-411. [CrossRef]

21. Mondal, R.; Miyaki, N.; Becerril, H.A.; Norton, J.E.; Parmer, J.; Mayer, A.C.; Tang, M.L.; Brédas, J.-L.; McGehee, M.D.; Bao, Z. Synthesis of acenaphthyl and phenanthrene based fused-aromatic thienopyrazine co-polymers for photovoltaic and thin film transistor applications. Chem. Mater. 2009, 21, 3618-3628. [CrossRef]

22. Urbach, F. The long-wavelength edge of photographic sensitivity and of the electronic absorption of solids. Phys. Rev. 1953, 92, 1324. [CrossRef]

23. Venables, J. Introduction to Surface and Thin Film Processes; Cambridge University Press: Cambridge, UK, 2000.

24. Pattanaik, A.K.; Srinivasan, A. Electrical and optical studies on Pb-modified amorphous Ge-Se-Te films. Semicond. Sci. Technol. 2003, 19, 157. [CrossRef]

25. Neamen, D.A. Semiconductor Physics and Devices: Basic Principles; McGraw-Hill: New York, NY, USA, 2012.

26. Muthalif, M.P.A.; Lee, Y.-S. Chozhidakath Damodharan Sunesh, Hee-Je Kim, and Youngson Choe. Enhanced photovoltaic performance of quantum dot-sensitized solar cells with a progressive reduction of recombination using Cu-doped CdS quantum dots. Appl. Surf. Sci. 2017, 396, 582-589. [CrossRef]

27. Guijarro, N.; Lana-Villarreal, T.; Mora-Seró, I.; Bisquert, J.; Gómez, R. CdSe quantum dot-sensitized TiO ${ }_{2}$ electrodes: Effect of quantum dot coverage and mode of attachment. J. Phys. Chem. C 2009, 113, 4208-4214. [CrossRef]

28. Shen, Q.; Kobayashi, J.; Diguna, L.J.; Toyoda, T. Effect of ZnS coating on the photovoltaic properties of CdSe quantum dotsensitized solar cells. J. Appl. Phys. 2008, 103, 084304. [CrossRef]

29. Rühle, S.; Shalom, M.; Zaban, A. Quantum-dot-sensitized solar cells. ChemPhysChem 2010, 11, 2290-2304. [CrossRef] 